\title{
Combining Ability of Six S7 Generation of Corn Hybrid Parents in Half Dialel Crosses
}

\author{
Niko Dwitama, Rustikawati, Dotti Suryati, Catur Herison \\ Department of Crop Production, Faculty of Agriculture, University of Bengkulu \\ WR Supratman St, Kandang Limun, Bengkulu 38371, Indonesia
}

\author{
ARTICLE INFO \\ Keywords: \\ hybrid \\ corn, \\ GCA, \\ SCA \\ Article history: \\ Received: March 24, 2018 \\ Accepted: June 26, 2018 \\ *Corresponding author: \\ E-mail: rustikawati@unib.ac.id
}

\begin{abstract}
Combining ability is the genotype's ability to pass on the desired character to the offspring. Combining ability information is needed to determine the crossed pairs in the formation of hybrid varieties. The purpose of this study was to obtain information on the combining ability value of six S7 generation of inbreed maize. The experiment was conducted in September 2015 until January 2016, at Medan Baru Experimental Station of Faculty of Agriculture, at Kandang Limun village, Muara Bangkahulu Sub-district, Bengkulu City. The experiment was prepared in a Randomized Block Design (RCBD) with 15 corn hybrid treatments including: G1XG3, G1XG6, G3XG6, G1XG7, G3XG7, G6XG7, G1XG8, G3XG8, G6XG8, G7XG8, G1XG9, G3XG9, G6XG9, G7XG9 and G8xG9. Each experimental unit was repeated three times obtaining 45 experimental plots. Estimation of general combining ability (GCA) value and specific combining ability (SCA) of each inbreed strain were conducted with Griffing model IV method. The results showed that genotype G1 and G3 had positive GCA values for all characters except plant height. The G7XG1 cross combination showed a positive SCA on all characters even higher in plant height and stem diameter. The G8XG6 cross combination showed high SCA values for leaf number characters, weight of husk-less cob, number of seeds per seed-line, weight of grain per ear, and grain yield per plot. .
\end{abstract}

\section{INTRODUCTION}

Corn (Zea mays) is an important source of food after rice. In addition to food, corn is also widely used as animal feed ingredients. The largest corn requirement is used for the feed industry $(57 \%)$, then for foodstuffs (34\%) and for other needs (9\%). Corn is very good as the main ingredient of animal feed because it contains $80 \%$ carbohydrate and protein 8 $11 \%$ (Vasal , 2001) of all dry ingredients of corn kernels.

National corn demand is increasing as the population grows. Based on data from Badan Ketahanan Pangan - (2015), the national corn production in 2013 amounted to 18,511,853 million tons of dry grain. Meanwhile, domestic demand for corn in the year reached 22 million tons. The shortage is filled with imports. One effort to reduce the import of maize is to increase the area of maize cultivation. The land available for expansion of the area is marginal land, especially outside of Java islands. To support the program, it is necessary to supply adaptive maize seeds to marginal lands.
Hybrid corn developed through plant breeding programs is the most effective way of obtaining superior corn hybrid varieties. According to Roy (2000) hybrid varieties are the generation of F1 from a cross between a pair or more inbreed parents (pure lines) that have superior properties. Superior hybrid varieties are typically characterized by high yielding. Hybridization is a potential technique in an effort to increase the yield of a commodity with the desired character.

Ruswandi et al. (2006) suggested that the selection of potential parental strains to produce superior hybrids need a relatively long activity and required substantial resources because the combination of crossings between lines in hybrid formation does not always result in superior hybrids. The initial evaluation in the formation of hybrid varieties is the evaluation of combining ability. This information is required to obtain a combination of parents which will produce high-yielding offspring. Wahyuni et al. (2004) stated that the parental selection directed to the ones which have a high general combining ability (GCA) or a combination of

ISSN: 1410-3354 / e-ISSN:2615-7136

Cited this as: Dwitama, N.,Rustikawati, D. Suryati, and C. Herison . 2018. Combining ability of six s7 generation of corn hybrid parents from half dialel crosses . Akta Agrosia 21(1):6-10. 
parents with specific combining ability (SCA) for the desired character so that produce superior offspring. High yields can be achieved if the derivatives of the crossed combination have high combining ability (Sujiprihati et al., 2007). Sujiprihati et al. (2008) also stated that combining ability is a measure of the ability of a plant genotype in crosses to produce superior plants. Combining ability analysis is an important method to estimate the action of genes and is often used by plant breeders to choose parents with a general joining ability and a high specific joining ability (Legesse et al., 2009; Zare et al., 2011). In order to assemble superior hybrid varieties, this study was conducted with the aim of obtaining information about the combining ability value of a cross-breed of six inbreed parents of S7 generation.

\section{MATERIALS AND METHOD}

The research was conducted in September 2015 until January 2016 in Medan Baru Experimenal Statioan of Faculty of Agriculture at Kandang Limun Village, Muara Bangkahulu Subdistrict, Bengkulu City, with the altitude of $15 \mathrm{~m}$ above sea level. The experiments were conducted in a Completely Randomized Block Design (RCBD) with three replications and 15 maize hybrids as the treatments. The tested hybrids were obtained from the half-diallel crosses of six S7 generation parents i.e. G1, G3, G6, G7, G8 and G9. The S7 generation was the inbreed line selected after selfing for seven generations. Half diallel crosses of the parents resulted in 15 hybrids, i.e. G1XG3, G1XG6, G3XG6, G1XG7, G3XG7, G6XG7, G1XG8, G3XG8, G6XG8, G7XG8, G1XG9, G3XG9, G6XG9, G7XG9 and G8xG9. Each experimental unit was a plot of $3 \mathrm{~m}$ wide and $3.6 \mathrm{~m}$ long.

Land preparation began by cleaning the weeds followed by first tillage by hoe of $20 \mathrm{~cm}$ in depth. The top soil section was reversed to the soil sub section. Cow manure in the rate of 20 ton.ha ${ }^{-1}$ was spread over the plots. The second land tillage was to mixed the manure with the soil thoroughly and make raise-bed plots of $3 \mathrm{~m} \times 3.6 \mathrm{~m}$. Distance between plot of treatment was $50 \mathrm{~cm}$ and distance between blocks was $100 \mathrm{~cm}$. There were 5 rows of plants $60 \mathrm{~cm}$ apart in each plot and each row consists of 12 plants $30 \mathrm{~cm}$ apart making up 60 plants population per plot.

Seeding was done manually by 'tugal' (wood stick of $5 \mathrm{~cm}$ in diameter, $1.5 \mathrm{~m}$ long, and sharp end) with a depth of $3 \mathrm{~cm}$, two seeds per hole. Carbofuran was applied simultaneously with the seed as much as 7 to 10 grains equivalent to a dose of $20 \mathrm{~kg} \cdot \mathrm{ha}^{-1}$ to prevent insect disturbance. At two weeks after planting the plants were thinned by leaving one plant per hill.

Urea, $\mathrm{KCl}$ and SP36 fertilizer of each $1.8 \mathrm{~g}$ per plant equivalent to a dose of $100 \mathrm{~kg} \cdot \mathrm{ha}^{-1}$ were applied at planting time. The second fertilization is done when the plant is 21 days after planting with a dose of $100 \mathrm{~kg} \cdot \mathrm{ha}^{-1}$ urea. The plants were watered as needed. At the age of 30 days, the plants were mounted by digging the soil between rows and dumping to the row to form a soil bund. Control of pest and diseases was carried out according to the conditions and symptoms of the attack. Weed control was done mechanically using crescent and hoe tools. Harvesting was done after the grains were full and dry. Characteristic of cob was ready to harvest was yellow colored, if the seeds pithy and shiny and hard.

The variables observed included plant height, stem diameter, number of leaves, cob weight without husk, ear length, ear diameter, number of seeds per seed row, dry seed weight, number of seeds per ear, and grain yield per plot. The data were analyzed statistically by analysis of variance with $5 \%$ level. GCA and SCA for each genotype were estimate following the method of Griffing's Model IV method (Singh and Chaudhary 1979).

$\mathrm{GCA}=\mathrm{gi}=1 / \mathrm{n}(\mathrm{n}-2)[\mathrm{nYi}$ - $-2 \mathrm{Y} .$.

$\mathrm{SCA}=\mathrm{Sij}=\mathrm{Yij}-1 / \mathrm{n}-2(\mathrm{Yi} .+\mathrm{Y} . \mathrm{j})+2 /(\mathrm{n}-1)(\mathrm{n}-2) \times \mathrm{Y}$.

where n, Yi., Y.., Yij, Y.j, Sij are number of parents, total sum of observation for second parent, grand total, average cross over $\mathrm{i}^{\text {th }} \times \mathrm{j}^{\text {th }}$ parent, the average number of $j^{\text {th }}$ crosses, and specific combining of apair of $i^{\text {th }}$ and $\mathrm{j}^{\text {th }}$ parent

\section{RESULTS AND DISCUSSION}

Characteristics of soil in the experimental site was sandy clay loam soil with $\mathrm{pH}\left(\mathrm{H}_{2} \mathrm{O}\right) 4.3$ (very acidic). At acidic soil, $\mathrm{P}$ element cannot be absorbed by plants because it is was bound by Al. C-Organic content of $1.51 \%$ (low), $\mathrm{K}_{\mathrm{dd}}$ of $0.77 \mathrm{me} / 100 \mathrm{~g}$ (high) and $\mathrm{Al}_{\mathrm{dd}}$ is very high with a value of $1.03 \mathrm{me} / 100 \mathrm{~g}$. The soil condition is less suitable for corn cultivation. To improve the physical and chemical properties of the soil in the field of research done the addition of cow manure with a dose of 20 ton.ha ${ }^{-1}$. Climatic factors such as rainfall, air temperature, solar irradiance and humidity were also very influential on plant growth. The total rainfall at the time of the plant to enter the vegetative growth phase was $64 \mathrm{~mm}$ month $^{-1}$. In October, it was no rain. During vegetative growth, rainfall was classified as insufficient. According to Rukmana (1997) the ideal rainfall for corn crops is $100-200 \mathrm{~mm} \mathrm{month}^{-1}$. The plants were watered every day with deep-well water. Entering the initial phase of flowering of maize plants requires adequate water availability. Sutoro et al. (1988) stated that to obtain good results, corn plants require sufficient water, especially in the flowering phase to fill the seeds. At the beginning of the generative phase of November and December total rainfall of $604.3 \mathrm{~mm}$ month $^{-1}$ and $741 \mathrm{~mm}$ month $^{-1}$ which were sufficient for grain filling stage.

At the end of the vegetative phase there are some plants that are afflicted with brownish disease (Peronosclerospora maydis). Plants afflicted with albino disease were revoked and kept away from the experimental field. To prevent the spread of the disease, chemically controlled by fungicide with active ingredient of propineb $70 \%$ with dose 3 g. $15 \mathrm{~L}^{-1}$. Sponge borer (Helicoverpa armigera) infects plants 
since the age of 61 days. Pest control was done by insecticide with active ingredient of Deltamethrin with a concentration of $1 \mathrm{~m} . \mathrm{L}^{-1}$.

\section{Analysis of the Varian Influence of 15 Maize Hybrids}

The treatment had a very significant effect on leaf number and diameter of cob without weight. While the effect on plant height, cob weight without husk, weight of grain per cob, number of grains per ear and grain yield per plot was significant (Table 1). The value of coefficient of variability (CV) was mostly variable below $20 \%$ except for the result of dry kiln per grain plot. According to Steel and Torrie (1981), the CV value indicates the level of accuracy of the study or may also state a percentage of the standard deviation against the average. Gomez and Gomez (1995) stated that the higher the CV value the lower the reliability of the study. High CV values on grain yield per plot were thought to be due to high variations in data because of environmental stress.

\section{General Combining Ability (GCA) Analysis}

Genotype G3 had a positive GCA value for all characters. The G1 genotype also had a positive GCA value for all characters except for the height character of the plant. While G9 was a genotype which had negative GCA values for all characters (Table 2). Genotype G1 was a good general combiner for stem diameter, husk-less cob weight, weight of grain per ear, and number of grain per ear. The good combiner for the number of leaves, the weight of the cobs without husk, the length of the ear, the number of seeds per grain-row, the weight of grains per ear, the number of grains per ear and grain yield per plot was the G3 genotype. Some other parents were good general combiner for a particular character. Roy (2000) explained that parents who have high and positive GCA values for a character indicate an additive gene action. Daryanto et al. (2010) statesd that parents who have high GCA values can be used as synthetic varieties for the characters studied.

Parents who have a positive GCA value were expected to have the ability to combine to other parents to produce genotypes with high yield potential. According to Sujiprihati et al. (2008) high and positive GCA values indicate that the parents on average produce superior hybrids when crossed with other parents. Fehr (1987) stated that the selection of good testers is helpful for breeders to select appropriate parents for breeding programs in the development of hybrid cultivars. Parents which have positive and high GCA values for some important characters can be directed as parents to assemble synthetic varieties. Genotype G3 had a positive GCA value for all characters. The G1 genotype also had a positive GCA value for all characters except for plant height. Thus, both of them were suitable for synthetic variety development.

\section{Specific Combining Ability (SCA) Analysis}

High SCA values are generally obtained from parents who have high GCA values (Sujiprihati et al., 2007; Iriany et al., 2011). However, in this study not all combinations of crosses of parents with positive

Table 1. Results of analysis of variance on growth and yield of corn

\begin{tabular}{|c|c|c|c|c|c|c|c|}
\hline \multirow{2}{*}{$\begin{array}{ll} & \text { Variables } \\
\text { Plant height }\end{array}$} & \multicolumn{2}{|c|}{ Genotype } & \multicolumn{2}{|c|}{ GCA } & \multicolumn{2}{|c|}{ SCA } & \multirow{2}{*}{$\begin{array}{r}\mathrm{CV}(\%) \\
10,28\end{array}$} \\
\hline & 2,37 & $*$ & 2,13 & ns & 2,50 & $*$ & \\
\hline Stem diameter & 1,18 & ns & & & & & 9,28 \\
\hline Number of leaf & 3,19 & $* *$ & 5,00 & $* *$ & 2,18 & ns & 7,18 \\
\hline Unhusked cob weight & 2,31 & $*$ & 2,80 & $*$ & 2,05 & ns & 16,67 \\
\hline Ear length & 1,52 & ns & & & & & 9,38 \\
\hline Unhusked cob diameter & 3,70 & $* *$ & 5,95 & $* *$ & 2,45 & $*$ & 5,15 \\
\hline Number of seed per grain-row & 2,06 & ns & & & & & 9,70 \\
\hline Grain weight per ear & 2,22 & $*$ & 3,16 & * & 1,70 & ns & 17,30 \\
\hline Number of grain per cob & 2,28 & $*$ & 1,67 & ns & 2,62 & $*$ & 14,83 \\
\hline Grain yield per plot & 2,62 & $*$ & 0,54 & ns & 3,78 & $* *$ & 37,07 \\
\hline
\end{tabular}

Note: $*=$ significantly different at the $5 \%$ level, $* *=$ very different at $1 \%$ level, and $\mathrm{ns}=$ not significantly different, $\mathrm{F}$ table genotype $5 \%=$ $2.06, \mathrm{~F}$ table genotype level $1 \%=2.79$

Table 2. General combining ability (GCA) value for growth and yield of corn

\begin{tabular}{cccccccccrr}
\hline Genotype & $\begin{array}{c}\text { Plant } \\
\text { height }\end{array}$ & $\begin{array}{c}\text { Stem } \\
\text { diameter }\end{array}$ & $\begin{array}{c}\text { Number } \\
\text { of leaf }\end{array}$ & $\begin{array}{c}\text { Unhuske } \\
\text { d cob } \\
\text { weight }\end{array}$ & $\begin{array}{c}\text { Ear } \\
\text { length }\end{array}$ & $\begin{array}{c}\text { Unhuske } \\
\text { d cob } \\
\text { diameter }\end{array}$ & $\begin{array}{c}\text { Number of } \\
\text { seed per } \\
\text { grain-row }\end{array}$ & $\begin{array}{c}\text { Grain } \\
\text { weight } \\
\text { per ear }\end{array}$ & $\begin{array}{r}\text { Number } \\
\text { of grain } \\
\text { per ear }\end{array}$ & $\begin{array}{r}\text { Yield } \\
\text { per plot }\end{array}$ \\
\hline G1 & $-2,19$ & 0,27 & 0,18 & 5,78 & 0,07 & 0,74 & 0,41 & 4,82 & 15,97 & 55,81 \\
G3 & 2,12 & 0,02 & 0,36 & 5,74 & 0,34 & 0,27 & 1,09 & 4,82 & 13,35 & 155,06 \\
G6 & $-3,53$ & $-0,55$ & $-0,91$ & 2,41 & 0,04 & 2,07 & $-0,84$ & 2,16 & 5,53 & 38,72 \\
G7 & $-0,88$ & 0,10 & 0,48 & 1,59 & 0,34 & $-0,14$ & 0,27 & 1,42 & 0,90 & 55,39 \\
G8 & 9,76 & 0,29 & 0,24 & $-6,89$ & $-0,51$ & $-2,01$ & $-0,16$ & $-6,53$ & $-13,13$ & $-110,44$ \\
G9 & $-5,28$ & $-0,13$ & $-0,36$ & $-8,64$ & $-0,28$ & $-0,94$ & $-0,76$ & $-6,69$ & $-22,62$ & $-194,53$ \\
\hline
\end{tabular}


GCA produce hybrids of high SCA (Table 3). Parents G8 and G6 had a negative GCA for the number of seeds per line. However, the G8XG6 crossover combination produces a high and positive SCA for the character. Similarly, G7XG1 crosses for plant height characters. Iriany et al. (2011) stated that the presence of genes which are beneficial to the genotype can cover harmful genes in the genotype of the partner so as to be able to show good combination.

A positive SCA score indicates that the parent had a high hybrid combination with other parent used. Conversely, if negative SCA means the parent does not have a high hybrid combination with any of other parent parents used. The highest SCA value for unhusked cob diameter was obtained from the cross of G9XG6 $(2,96)$. While the lowest SCA value for the character was obtained from the genotype cross of G3XG8 (-0.11). High SCA values in the character of the diameter of cob without husk was also obtained by Abdel-Moneam et al. (2009).

The G8 genotype had a negative GCA for some characters. Genotype G6 was a good and positive general combiner for some of the same characters. The G8XG6 crossover combination has the highest SCA value for that character character. Crossings between genotypes that have positive GCA with genotypes that have negative GCA, generally have a high SCA effect.

Hybrids that exhibit high SCA were usually produced from crosses of parents with high $\mathrm{x}$ high, high $\mathrm{x}$ low GCA or at least one having high GCA (Daryanto et al., 2010; Sujiprihati et al., 2007). According to Virmani (1994), hybrids having high SCA values were usually produced from recombination of crosses with at least one parent having a high GCA value. Mangoendidjojo (2007) stated that the value of SCA was an indicator of the action of dominant genes and epistasis. While, the value of GCA indicates the existence of gene action of additive that controls a character. High specific combining ability is supported with a positive dominant variety value will give better results.

The G7XG1 cross combination had a positive SCA value for all characters and was the highest for plant height and stem diameter. According to Sujiprihati et al. (2008) the combination of crosses with high SCA values may be considered as the hybrid-forming parents. Thus the G8XG6 cross combination had positive and high SCA values for leaf number characters, unhusked cob weight, number of seeds per grain-row, weight of grain per ear, and grain yield. Therefore, G8XG6 was a highly prospective hybrid. Further field evaluation is required to prove the hybrid is high yielding.

\section{CONCLUSION}

Parent G3 had a positive general combining ability value for all observed variables. The G7XG1 cross has positive specific combining ability value for all variables and has a high specific combining ability for plant height variables and stem diameter.

The G8XG6 cross had a specific combining ability value for leaf number variables, unhusked cob weight, number of seeds per grain-row, weight of grain per ear, and grain yield per plot. The hybrid was the most prospective hybrid for high yield.

\section{ACKNOWLEDGEMENT}

This research is part of the National Strategic Research of Fiscal Year 2015 funded by the Ministry of Research,Technology and Higher Education.

\section{REFERENCES}

Abdel-Moneam, M.A., A.N. Attia, M.I. El-Emery, E.A. Fayed. 2009. Combining ability and heterosis for some agronomic traits in crosses of maize. Pakistan. J. Biol. Sci. 12:433-438.

Badan Ketahanan Pangan, 2015. Data statistik ketahanan pangan tahun 2014. BK Pangan- Jakarta

Table 3. Specific Combining Ability (SCA) value of 15 hybrids

\begin{tabular}{lcccccccccc}
\hline Genotype & $\begin{array}{c}\text { Plant } \\
\text { height }\end{array}$ & $\begin{array}{c}\text { Stem } \\
\text { diameter }\end{array}$ & $\begin{array}{c}\text { Number } \\
\text { of leaf }\end{array}$ & $\begin{array}{c}\text { Unhusk } \\
\text { ed cob } \\
\text { weight }\end{array}$ & $\begin{array}{c}\text { Ear } \\
\text { length }\end{array}$ & $\begin{array}{c}\text { Unhusked } \\
\text { cob } \\
\text { diameter }\end{array}$ & $\begin{array}{c}\text { Number of } \\
\text { seed per } \\
\text { grain-row }\end{array}$ & $\begin{array}{c}\text { Grain } \\
\text { weight } \\
\text { per ear }\end{array}$ & $\begin{array}{c}\text { Number } \\
\text { of grain } \\
\text { per ear }\end{array}$ & $\begin{array}{c}\text { Yield per } \\
\text { plot }\end{array}$ \\
\hline G3XG1 & 0,49 & $-0,62$ & 0,52 & 0,03 & $-0,57$ & 0,07 & $-0,34$ & $-2,59$ & $-2,30$ & 126,52 \\
G6XG1 & $-5,66$ & $-0,24$ & $-0,41$ & $-3,50$ & $-0,13$ & $-0,29$ & 0,46 & 0,68 & 8,31 & 42,85 \\
G6XG3 & 12,16 & 0,51 & $-0,26$ & $-11,40$ & $-0,73$ & $-0,70$ & $-3,09$ & $-9,59$ & $-26,47$ & $-623,07$ \\
G7XG1 & 15,49 & 1,30 & 0,21 & 11,12 & 1,03 & 2,24 & 0,67 & 6,21 & 23,95 & 326,18 \\
G7XG3 & $-13,23$ & $-1,29$ & $-0,31$ & $-2,25$ & $-0,57$ & 0,35 & $-0,14$ & 0,15 & $-20,24$ & 260,27 \\
G7XG6 & $-8,31$ & $-0,85$ & $-0,51$ & $-7,05$ & $-0,07$ & $-2,63$ & $-0,54$ & $-4,72$ & $-27,29$ & $-622,07$ \\
G8XG1 & $-6,28$ & $-1,61$ & $-0,96$ & $-11,67$ & $-1,12$ & $-1,02$ & $-2,56$ & $-8,24$ & $-58,15$ & $-1104,98$ \\
G8XG3 & 10,21 & 0,51 & 0,26 & 7,83 & 1,22 & $-0,11$ & 2,09 & 6,16 & 27,06 & 526,10 \\
G8XG6 & $-10,81$ & 1,09 & 1,12 & 15,90 & 1,05 & 0,65 & 2,82 & 9,23 & 35,81 & 942,43 \\
G8XG7 & 5,94 & 1,20 & 0,34 & 0,98 & $-0,12$ & 1,45 & 0,64 & 2,70 & 39,31 & 125,77 \\
G9XG1 & $-4,04$ & 1,17 & 0,64 & 4,02 & 0,78 & $-1,00$ & 1,77 & 3,93 & 28,20 & 609,43 \\
G9XG3 & $-9,63$ & 0,90 & $-0,21$ & 5,78 & 0,65 & 0,40 & 1,49 & 5,86 & 21,95 & $-289,82$ \\
G9XG6 & 12,62 & $-0,51$ & 0,06 & 6,05 & $-0,12$ & 2,97 & 0,36 & 4,40 & 9,63 & 259,85 \\
G9XG7 & 0,11 & $-0,36$ & 0,27 & $-2,80$ & $-0,28$ & $-1,40$ & $-0,63$ & $-4,34$ & $-15,74$ & $-90,15$ \\
G9XG8 & 0,94 & $-1,20$ & $-0,76$ & $-13,05$ & $-1,03$ & $-0,98$ & $-2,99$ & $-9,85$ & $-44,04$ & $-489,32$ \\
\hline
\end{tabular}


Daryanto, A., S. Sujiprihati, M. Syukur. 2010. Heterosis dan daya gabung karakter agronomi cabai (Capsicum annuum L.) hasil persilangan half diallel. J. Agron. Indonesia 38(2):113-121.

Fehr,W.R. 1987. Principles of Cultivar Development. Volume. 1. (Theory and Technique). New York (US): MacMillan.

Gomez, K.A. dan A.A. Gomez. 1995. Prosedur Statistik untuk Penelitian Pertanian. Terjemahan dari: Statistical Procedurs for Agriculture Research. Penerjemah: E.Sjamsudin dan J.S. Baharsjah. Penerbit Universitas Indonesia. Jakarta. 698 hal.

Iqbal, A.M., F.A. Nehvi, S.A. Wani, R. Qadir, and Z.A. dar. 2007. Combining ability analysis for yield and yield related traits in maize (Zea mays L.). Int. J. Plant Breed. and Gen. 1(2): 101-105

Iriany, R.N., S. Sujiprihati, M. Syukur, J. Koswara, M. Yunus. 2011. Evaluasi daya gabung dan heterosis lima galur jagung manis (Zea mays var saccharata) hasil persilangan dialel. (Evaluation of combining abilityand heterosis of five sweet corn lines (Zea mays var saccharata) from a dialel crosses. Indonesian Language) J. Agron. Indonesia 39(2):103-111.

Legesse, B.W., K.V. Pixley, A.M. Botha. 2009. Combining ability and heterotic grouping of highland transsition maize inbred lines. Maydica 54(1):9-14.

Mangoendidjojo W. 2007. Dasar-Dasar Pemuliaan Tanaman (Fundamentals of Plant Breeding. Indonesian Language). Kanisius. Yogyakarta

Roy, D. 2000. Plant Breeding. Analysis and Exploitation of Variation. Alpha Science intl Ltd. New Delhi.

Rukmana, R. 1997. Usaha Tani Jagung (Corn Farming. Indonesian Laguage). Kanisius. Yogyakarta.

Ruswandi, D., M.M. Basuki, Annissa, S. Ruswandi, N. Rostini. 2006. Daya gabung galur-galur downy mildew resistant (DMR) dan quality protein maize (QPM) berdasarkan analisis line $\mathrm{x}$ tester (Combination of downey mildew resistant (DMR) and quality protein maize (QPM) lines based on line $\mathrm{x}$ tester analysis. Indonesian Language). Zuriat 17(1):25-35.

Singh, R.K dan R.D. Chaundary. 1979. Biometrical Methods in Quantitative Genetic Analysis. Kalyani Publishers. New Delhi. p.301.

Sujiprihati, S., M. Syukur, R. Yunianti. 2008. Pemuliaan Tanaman (Plant Breeding. Indonesian Language). Departemen Agronomi dan Hortikultura, IPB. Bogor.

Sujiprihati, S., R. Yunianti, M. Syukur, Undang. 2007. Pendugaan nilai heterosis dan daya gabung beberapa komponen hasil pada persilangan dialel penuh enam genotipe cabai (Capsicum annuum L.) (Estimation of heterosis value and the combining ability of several component components on a full dialed crossover of six chili genotypes (Capsicum annuum L.). Indonesian Language). Bul. Agron. 35(1):28-35.

Sutoro, Y. Soelaeman, \& Iskandar. 1988. Budidaya Tanaman Jagung (Cultivation of Corn Crops. Indonesian Language). Balai Penelitian Tanaman Pangan. Bogor.

Vasal, S.K. 2001. High quality protein corn. In Hallauer, A.R. (Ed.). Specialty Corns. Second Ed. CRC Press, London. 85-129.

Virmani SS. 1994. Heterosis and Hybrid Rice Breeding. Monographs on Theoretical and Applied Genetics 22. Springer Verlag. Berlin.

Wahyuni, T.S., R. Setiamihardja, N. Herniati, K.H. Hendroatmodjo. 2004. Variabilitas genetik, heritabilitas dan hubungan antara hasil umbi dengan beberapa karakter kuantitatif dari 52 genotip ubi jalar di Kendalpayak, Malang (Genetic variability, heritability and relationship between some tuber yields with some quantitative of 52 sweet potato genotypes in Kendalpayak, Malang. Indonesian Language). Zuriat 15(2):109-116.

Zare, M., R. Choukan, E.M. Heravan, M.R. Bihamta, K. Ordookhani. 2011. Gene action of some agronomic traits in corn (Zea mays L.) using diallel cross analysis. African. J. Agric. Res. 6 (3):693-703. 